\title{
Nonfat Dairy Coffee Whitener Made from Ultrafiltered Skimmilk Retentates
}

\author{
R. JIMENEZ-FLORES and F.V. KOSIKOWSKI
}

\section{ABSTRACT}

Retentates of different protein concentrations obtained by ultrafiltration of skimmilk were freeze-dried and evaluated as nonfat dairy coffee whiteners. Blended in hot coffee the retentate whiteners containing added riboflavin gave a $\mathrm{pH}$ of $6.3-6.55$, coffee whitening capacity comparable to a commercial nondairy coffee creamer, and acceptable dispersibility. The retentate nondairy whitener with optimum qualities contained $56 \%$ total protein, $0.5 \%$ fat, $31.0 \%$ carbohycirates, $1.92 \%$ calcium, and $27 \mathrm{mg}$ sodium/100g.

\section{INTRODUCTION}

NONDAIRY COFFEE CREAMERS (NDCC) are composed largely of corn syrup solids and vegetable fats, according to Lampert (1970). Posati and Orr (1976) and Jolly and Kosikowski (1978) report that a very high percentage of the fatty acids in commercial NDCC are saturated.

Ultrafiltration (UF) can produce dried skimmilk retentates that display different composition and physical properties and improved nutritional value compared to standard skimmilk powders (Jimenez-Flores, 1984; Jimenez-Flores and Kosikowski, 1985). The objective of the present study was to assess the potential of ultrafiltered skimmilk retentate powders as nonfat dairy coffee whiteners.

\section{MATERIALS \& METHODS}

FOR EACH TRIAL 320 liters of freshly drawn, raw Holstein milk from the Cornell University Veterinary farm were heated to $54^{\circ} \mathrm{C}$. Three-quarters of this milk volume was ultrafiltered in an Abcor $22 \mathrm{~S}$ UF unit with $2 \mathrm{~m}^{2}$ of polysulfone high flux membranes, possessing a molecular weight cut-off of 20,000 daltons. Inlet and outlet pressures were 310.3 and $103.4 \mathrm{kPa}$, respectively. Three retentate lots at $2: 1$, $3: 1$, and $4: 1$ volume concentration were produced. A fourth lot, that of the heated raw milk, serving as a control, was concentrated to $20 \%$ total solids (T.S.) in an APV falling film plate evaporator (model J.P.W.). Condensed milk control and the retentates then were mechanically separated in a De Laval (Model 242) separator and pasteurized at $72^{\circ} \mathrm{C}$ and $15 \mathrm{sec}$. These lots were freeze-dried in a Virtis UE 800 unit and resulting flakes were mechanically milled. Powder A was a control from condensed skimmilk. Powders B, C, and D were from skimmilk retentates ultrafiltered to $2: 1,3: 1$ and $4: 1$ volume concentration. For comparative purposes commercial NDCC were obtained as well as a commercial low-heat skimmilk powder.

Riboflavin (Eastman Kodak reagent) and beta-carotene (Sigma Chemicals) were added to retentate nonfat dairy whiteners at $10 \mathrm{mg} /$ $100 \mathrm{~g}$ powder to enhance color.

\section{Analysis}

A. HunterLab Color Difference-meter, Model D25, (Hunter Associates Laboratory, Fairfax, VA) was used to quantitate whitening capacity and color differences in $80^{\circ} \mathrm{C}$ coffee of nonfat retentate dairy whiteners and a NDCC. Two grams powder were dissolved in 250 $\mathrm{mL}$ of a 'standard coffee solution', ( $4 \mathrm{~g}$ Maxwell House instant coffec in $500 \mathrm{~mL}$ hot water). Color analyses made in triplicate are described
Table 1-Properties of individual skimmilk retentate powders

\begin{tabular}{|c|c|c|c|c|c|}
\hline & \multicolumn{4}{|c|}{$\begin{array}{c}\text { Freeze-dried } \\
\text { powders }\end{array}$} & \multirow{2}{*}{$\begin{array}{c}\begin{array}{c}\text { Nondairy } \\
\text { coffee creamen } \\
\text { powder }\end{array} \\
Y\end{array}$} \\
\hline & A & $B$ & C & D & \\
\hline $\begin{array}{l}\mathrm{pH} \text { in hot coffee } \\
\text { Total color }\end{array}$ & 6.00 & 6.30 & 6.45 & 6.55 & 6.30 \\
\hline $\begin{array}{l}\text { difference } \\
\text { in hot coffee }\end{array}$ & 6.52 & 5.48 & 4.37 & 3.40 & 7.20 \\
\hline $\begin{array}{l}\text { Percent disper- } \\
\text { sability in wa- } \\
\text { ter }\end{array}$ & 34 & 32 & 32 & 33 & 100 \\
\hline
\end{tabular}

a produced from laboratory skimmilk powder control, B from 2:1 UF retentate, $C$ from $3: 1$ UF retentate, $D$ from $4: 1$ UF retentate, $Y=$ national brand.

${ }^{b}$ Fresh unwhitened coffee $\mathrm{pH}=5.30$.

c Commercial low heat skimmilk powder displayed a dispersability value of 37.

elsewhere with more detail (Jimenez-Flores, 1984). Also, color photographs were taken of the coffees.

Dispersibility of the powders was measured in $24^{\circ} \mathrm{C}$ water as percentage values by the method of Baldwin (1977) and in hot coffee visually by the authors. The $\mathrm{pH}$ of the whitened coffee was determined by a Beckman Expandomatic potentiometer.

\section{RESULTS}

TOTAL COLOR DIFFERENCE, $\mathrm{pH}$ and dispersibility of the five experimental powders are shown (Table 1). Nonfat dairy whiteners, identified as skimmilk retentate powders, adding to hot, black coffee $(\mathrm{pH} 5.3)$ shifted the $\mathrm{pH}$ from 6.3 to 6.55 , equalling, or slightly exceeding, the $\mathrm{pH}$ when the same black coffee was colored by a NDCC. Color difference $(\triangle E)$ of hot coffee containing nonfat dairy whiteners compared against a white standard, were less than those for a commercial skimmilk powder control and a NDCC. Value for NDCC dispersibility in water was $100 \%$ and for nonfat dairy whiteners 32 $34 \%$. Powder 1 , and commercial low heat skimmilk powder, both controls, showed dispersibility values between 34-39\%. In hot coffee NDCC was observed to disperse immediately whereas nonfat dairy coffee whiteners dispersed more slowly but uniformly.

The whitening capacity and color difference of only UF skimmilk retentate powders $\mathrm{C}$ and $\mathrm{D}$ in hot coffee are presented in Table 2. These powders were selected because of their higher nutritional qualities. Small additions of riboflavin in particular enhanced color quality and equalized to a great extent color differences, eliminating a greyish cast which was apparent visually.

Color photographs, not shown, record that a commercial low heat skimmilk powder compared to retentate nonfat dairy whiteners or to a NDCC appears deficient in hot coffee whitening power. Conversely nonfat dairy whiteners $C$ and $D$ containing added riboflavin show good whitening power in hot coffee, equal to that of a NDCC.

\section{DISCUSSION}

NONFAT DAIRY COFFEE WHITENER C contained $56.4 \%$ protein, $0.5 \%$ fat, $31.4 \%$ carbohydrate, $1.9 \%$ calcium, and $27.5 \mathrm{mg}$ sodium per $100 \mathrm{~g}$. By contrast Posati and Orr (1976) 
Table 2-Whitening capacity nonfat dairy whiteners $C$ and $D$ in hot coffee

\begin{tabular}{|c|c|c|c|c|c|c|c|c|c|c|c|}
\hline $\begin{array}{l}\text { Whitener } \\
\text { powder }\end{array}$ & $\mathrm{L}^{a}$ & $A^{a}$ & $\mathrm{~B}^{\mathrm{a}}$ & $D^{b}$ & $\mathrm{Da}$ & $\mathrm{Db}$ & DE & $\mathrm{dL}^{\mathrm{c}}$ & $\mathrm{da}$ & $\mathrm{db}$ & $\mathrm{dE}$ \\
\hline C & $\begin{array}{l}46.9 \\
(1.2)\end{array}$ & $\begin{array}{c}3.7 \\
(0.1)\end{array}$ & $\begin{array}{l}15.3 \\
(0.9)\end{array}$ & 46.2 & 4,5 & 25.9 & 49.06 & 1.4 & 0 & 3.5 & 3.77 \\
\hline$C+R+$ Beta & $\begin{array}{l}47.3 \\
(1.3)\end{array}$ & $\begin{array}{c}3.7 \\
(0.1)\end{array}$ & $\begin{array}{l}15.7 \\
(0.8)\end{array}$ & 45.8 & 4.5 & 16.3 & 48.5 & 1.0 & 0 & 3.1 & 3.26 \\
\hline$C+R$ & $\begin{array}{l}47.1 \\
(1.2)\end{array}$ & $\begin{array}{c}3.5 \\
(0.1)\end{array}$ & $\begin{array}{l}26.0 \\
(1.0)\end{array}$ & 46.0 & 4,3 & 16.6 & 49.1 & 1.2 & 0.2 & 2.8 & 3.05 \\
\hline C+Beta & $\begin{array}{l}47.3 \\
(1.2) \\
\end{array}$ & $\begin{array}{c}3.7 \\
(0.1) \\
\end{array}$ & $\begin{array}{l}15.4 \\
(0.9) \\
\end{array}$ & 45.8 & 4,5 & 16.0 & 48.7 & 1.0 & 0 & 3.4 & 3.54 \\
\hline D & $\begin{array}{l}48.55 \\
(1.3)\end{array}$ & $\begin{array}{c}3.3 \\
(0.1)\end{array}$ & $\begin{array}{l}14.6 \\
|1.1\rangle\end{array}$ & 44.6 & 4.1 & 15.2 & 47.3 & 0.25 & 0.2 & 4.2 & $\overline{4,2}$ \\
\hline$D+R+B e t a$ & $\begin{array}{l}48.9 \\
(1.2)\end{array}$ & $\begin{array}{c}3.1 \\
(0.1)\end{array}$ & $\begin{array}{l}15.4 \\
(1.0)\end{array}$ & 48.6 & 3.9 & 16.0 & 47.2 & -0.6 & 0.6 & 3.4 & 3.5 \\
\hline$D+R$ & $\begin{array}{l}49.0 \\
(1.2)\end{array}$ & $\begin{array}{c}2.8 \\
(0.1)\end{array}$ & $\begin{array}{l}15.3 \\
(0.1)\end{array}$ & 44.1 & 3.6 & 15.9 & 47.0 & -0.7 & 0.9 & 3.5 & 3.5 \\
\hline$D+$ Beta & $\begin{array}{l}48.8 \\
(1.4) \\
\end{array}$ & $\begin{array}{c}3.2 \\
(0.1) \\
\end{array}$ & $\begin{array}{l}14.8 \\
(1.2) \\
\end{array}$ & 44.3 & 4.0 & 15.4 & 47.1 & -0.5 & 0.5 & 4.0 & 4.1 \\
\hline $\begin{array}{l}\text { White } \\
\text { Standard }\end{array}$ & 93.1 & -0.8 & -0.6 & 0 & 0 & 0 & - & - & - & - & - \\
\hline NDCC & 48.3 & 3.7 & 18.8 & 44.8 & 4.5 & 19.4 & 49.03 & 0 & 0 & 0 & 0 \\
\hline
\end{tabular}

arithmetic mean of 2 determinations for 4 samples, values in ( ) are standard deviations. $L=$ Lightness, 100 perfect white, 0 perfect black; $A=$ redness; $B=$ yellowness.

b $D$ - (columns $5-8$ ) indicates that the difference has been taken from the white standard.

c $\mathrm{d}-$ (columns $9-12$ ) indicates that the difference is with respect to the NDCC.

$d a=$ Redness when + , greeness when - , gray when $0 ; b=$ Yellowness when + , blueness when -, gray when $0 ; E=$ Total color difference,

- Powders $C$ and $D$ were $3: 1$ and 4:1 skimmilk retentates, respectively. NDCC $=$ Nondairy coffee creamer; $R$ and Beta (column 1$)=$ riboflavin and beta-carotene.

list NDCC powders on the average as containing $4.8 \%$ protein, $35.5 \%$ fat, $54.9 \%$ carbohydrate, $0.02 \%$ calcium and $181 \mathrm{mg}$ sodium per $100 \mathrm{~g}$. Nonfat dairy coffee whitener $\mathrm{C}$ is preferred over whitener $D$ because greater opportunity exists for sedimentation at protein levels above $60 \%$ as observed visually and because it is less expensive to produce.

Although NDCC powders dispersed into hot coffee immediately, under the same conditions, retentate nonfat dairy whitener C and D dispersed satisfactorily after one spoon rotation. Spray dried, nonfat dairy whiteners were also produced in the laboratory from the same liquid retentates. Dispersibility of the higher protein spray-dried retentates was not fully satisfactory, a condition which may be corrected by instantizing or agglomerating the powder and attaining better control over variables during commercial spray drying.

Three additional commercial NDCC powders obtained for more detailed studies involving functionality, influenced whitening of hot coffee to approximately the same degree as the NDCC used specifically for the coffee creamer study. NDCC whitening effects are mainly achieved from fat and artificial colors while those of retentate nonfat dairy whiteners are ob- tained through milk protein and added riboflavin or beta-carotene. Such whiteners may have the potential also for use in concentrated liquid form, perhaps aseptically packaged.

\section{REFERENCES}

Baldwin, A.J. 1977. The appearances of whole milk powders as related to physical properties. New Zealand J. Dairy Sci. Tech. 12: 201

Jimenez-Flores, R. 1984. Physical and functional properties of ultrafiltered Jimenez-Flores, R. 1984. Physical and functional properties of ultrafiltered
skimmilk retentate powder. M.S. thesis, Cornell Univ., Ithaca, New York. skimmilk retentate powder. M.S. thesis, Cornell Univ., Ithaca, New York.
Jimenez-Flores, R. and Kosikowski, F.V. 1984. Functional properties of dried skimmilk ultrafiltration retentates. J. Dairy Sci. (suppl. 1) 67: 77. Jimenez-Flores, R. and Kosikowski, F.V. 1985. Properties of ultrafiltered skimmilk retentate powders. J. Dairy Sci. 68: in review.

Jolly, R.C. and Kosikowski, F.V. 1974. Fat characteristics of nondairy and dairy powdered creamers. J. Agric. Food Chem. 22(2): 296.

Lampert, L.M. 1970. "Modern Dairy Products," 397 . Chemical PublishLampert, L.M. 1970 . "Moc

ing Co. Inc., New York.
Posati, L.P. and Orr, M.L. 1976. "Composition of Foods. Dairy and Egg Products. USDA-ARS, Handbook 8-1. Washington, DC

$\mathrm{Ms}$ received $7 / 31 / 85 ;$ accepted $9 / 29 / 85$

The authors express their appreciation to Dairy Research Incorporated (DRINC) (Rosemont, IL, for supporting this study in part. 